\title{
Bemötanden av främlingsfientlighet i gymnasieskolan
}

\author{
Emma Arneback
}

SAMMANDRAG: I den här artikeln analyserar Emma Arneback lagar, styrdokument och likabehandlingsplaner för gymnasieskolan för att undersöka hur uppdraget att bemöta främlingsfientlighet i skolan har förändrats under de senaste 20 åren. Hon undersöker vilka konsekvenser olika bemötanden kan medföra för a) yttrandefrihetens gränser i skolan och b) vem eller vad som ses som främlingsfientlig eller främlingsfientligt. Resultatet visar att uppdraget har gått från att vara ett decentraliserat etiskt ansvar (1994-2006) till att bli ett centraliserat juridiskt ansvar (2006-). Förskjutningen påverkar yttrandefrihetens gränser i skolan och för med sig olika uttolkningar av i vilken mån det är möjligt att tala om det som är svårt och kan såra i skolans värld. Arnebacks analys av likabehandlingsplanerna visar även på att skolorna i hög grad fokuserar på att bemöta främlingsfientliga individer, medan frågan om att motverka de strukturer som skapar förutsättningar för individer att verka förtryckande lämnas därhän.

NYCKELORD: främlingsfientlighet; gymnasieskolan; utbildningspolitik; yttrandefrihet; likabehandlingsplaner.

PUBLICERINGSHISTORIK: Originalpublicering.

EMMA ARNEBACK är lektor i pedagogik vid Örebro universitet.

FÖRSLAG PÅ KÄLLANGIVELSE:

Arneback, Emma (2013) "Bemötanden av främlingsfientlighet i gymnasieskolan", i Det vita fältet II. Samtida forskning om högerextremism, specialnummer av Arkiv. Tidskrift för sambällsanalys, $\mathrm{nr} 2$, s. 139-165.

DOI: http://dx.doi.org/IO.I3068/2000-6217.2.5

(C) Emma Arneback/Arkiv förlag \& tidskrift 2013 (publicerad I6 september 2013)

Artikeln distribueras enligt en upphovsrättslicens från Creative Commons:

Erkännande-Ickekommersiell-IngaBearbetningar 3.0 Unported, som medger fri ickekommersiell användning och spridning i oförändrat skick så länge källan anges. 
Arkiv. Tidskrift för samhällsanalys är en sakkunniggranskad vetenskaplig tidskrift för samhällsvetenskap och historia. Samtliga artiklar publiceras fritt tillgängliga på:

$$
\text { www.tidskriftenarkiv.se }
$$

(beständig länk, DOI: http://dx.doi.org/IO.I3068/200o-62I7)

Den här artikeln finns tillgänglig i följande format:

PDF \& HTML: via beständig länk, DOI: http://dx.doi.org/IO.I3068/2000-6217.2.5 EPUB: ingår i e-boksutgåva av numret, ISBN: 978 9I 7924254 I TRYCK: ingår i bokutgåva av numret, ISBN: 978 9I 79242558

Grafisk utformning och sidnumrering är identisk i pdf och tryck.

Samtliga artiklar i nr 2 (2013), Det vita fältet II. Samtida forskning om högerextremism, nås via beständig länk, DoI: http://dx.doi.org/I0.13068/2000-6217.2 redaktion för numret: Mats Deland, Paul Fuehrer och Fredrik Hertzberg

Arkiv. Tidskrift för sambällsanalys ISSN: 2000-62I7 (för elektronisk resurs) ISSN: 2000-6225 (för tryckta nummer)

ges ut av

Stiftelsen Arkiv för främjande och spridning av samhällsvetenskaplig och historisk forskning

genom

Arkiv förlag \& tidskrift

Box 1559 SE-22I OI Lund BESÖK: L Gråbrödersg 3 c, ipg TEL: O46-I3 3920

ARKIV FÖRLAG: arkiv@arkiv.nu·www.arkiv.nu TIDSKRIFTEN ARKIV: red@tidskriftenarkiv.se · www.tidskriftenarkiv.se

ANSVARIg UTGIVARE \& CHEFREDAKTÖR: Sven Hort AdMinistrativ Redaktör: David Lindberg ReDAKTörer: Paavo Bergman, Lisa Kings, Zhanna Kravchenko 


\title{
Bemötanden av främlingsfientlighet i gymnasieskolan
}

\author{
EMMA ARNEBACK
}

\author{
Det kallas chocktillstånd \\ när orden bränns \\ inpå bara skinnet. \\ Det kallas chocktillstånd \\ när tankar känns \\ och skär som bitar av glas \\ små, små sår under linningen. \\ Ur "Att presentera ett svin" av Kent, \\ från albumet B-sidor 95-oo.
}

Fientlighet är en känsla som kan vara tung att bära och förtvinande att möta. I situationer där det gör ont ställs vi inför varandra, oss själva och våra handlingar på ett närmast brutalt sätt. Kanske eftersom det är i sådana stunder som det blir som mest betydande hur vi anropar världen, och vilka möjligheter som därmed öppnas och stängs. Förekomsten av främlingsfientliga uttryck i skolan medför att pedagoger ställs inför svåra val och frågor om vad som är ett gott, riktigt eller fruktbart bemötande i dessa svåra situationer. Problematiken har också bidragit till att det skapas olika lagar, program och planer som ska vägleda dessa handlingar. I denna artikel analyseras lagar, styrdokument och likabehandlingsplaner för gymnasieskolan med syftet att studera hur förhållningssättet till 
bemötandet av främlingsfientlighet i skolan har förändrats sedan $1994{ }^{\mathrm{I}}$ Därefter studeras vilka konsekvenser de olika förhållningssätten kan medföra för a) yttrandefrihetens gränser i skolan och b) vem eller vad som pekas ut som främlingsfientlig eller främlingsfientligt. Utifrån detta görs en jämförande analys som visar på vilka konflikter som uppstår när de olika förhållningssätten ställs emot varandra.

\section{Tillvägagångssätt}

Metodologiskt är studien inspirerad av den amerikanska pragmatismen, och framför allt pedagogen och filosofen John Dewey. Till den amerikanska pragmatismens epistemologi hör en metod för kunskapsproduktion eller kunskapande som strävar efter att låta olika perspektiv framträda i relation till en på förhand formulerad fråga, för att därigenom tydliggöra vilka handlingar och konsekvenser de olika perspektiven kan föra med sig (Biesta \& Burbules 2003, s. 56 ff.). Epistemologin implicerar således även en pragmatisk moralfilosofisk ståndpunkt. John Deweys moralfilosofi har också varit vägledande vid utformningen av denna studie. Dewey menar att människor bör reflektera över handlingsalternativ för att inte fastna i vanor eller fastslagna principer; "frågan är inte vad vi ska göra, utan hur vi ska besluta vad vi ska göra" (Dewey 197I [1892-I893], s. 56, min övers.). Om vi fokuserar på hur i stället för vad, skapas, enligt Dewey, förutsättningar för olikhet att framträda och övervägas:

Vi ger utrymme, i våra sinnen, till vissa impulser; vi provar, i våra sinnen, vissa planer. Genom att följa dem genom olika steg, finner vi oss själva fantisera i närvaro av de konsekvenser som skulle följa; och som vi sedan gillar och godkänner, eller ogillar och förkastar, genom dessa konsekvenser, finner vi att impulsen eller planen är bra eller dålig (Dewey \& Tufts 1985 [1932], s. 275, min övers.).

Med detta pragmatiska perspektiv fokuserar vi kommunikation och förändring. Det är just behovet av att pröva och samtala om olika handlingsalternativ som är drivkraften för analysen i denna artikel. Strävan är inte att finna ett rätt svar, utan att tydliggöra att det finns olika sätt att

I. Att tidsperioden påbörjas år 1994 beror på att det då kom nya läroplaner som för första gången tog upp frågan om bemötandet av främlingsfientlighet i skolan. 
förhålla sig till en specifik problematik, och att de får olika konsekvenser. Därigenom kan vi också foga samman frågan om var vi är i dag med vart vi kan och vill hamna i framtiden (Cherryholmes 1999, s. 3 ff.).

Pragmatismen erbjuder ingen specifik metod för textanalys. Andra forskare som har genomfört textanalyser inspirerade av pragmatismen har beskrivit dem som syftesrelaterade textanalyser (Säfström \& Östman I999, s. I9 ff.). Benämningen markerar att syftet är att studera hur olika texter svarar på en specifik fråga. Analysen ses som en av många möjliga och syftar till att tydliggöra olika perspektiv. Min textanalys har i den andan genomförts med utgångspunkt i följade frågeställning: Vilka kommunikationsideal och handlingsinriktningar förespråkas vid bemötandet av främlingsfientliga uttryck, och vilka konsekvenser kan dessa rekommendationer medföra för synen på skolans uppdrag, lärarens ansvar samt yttrandefrihetens gränser?2 I artikeln fokuseras främst vilka handlingar som förespråkas vid bemötandet av främlingsfientlighet.

Texterna har analyserats intratextuellt och intertextuellt (jfr Ljunggren 1996, s. I45). I den intratextuella läsningen studeras den enskilda texten, den inre logiken och eventuella motsättningar. I denna fas har jag valt att använda mig av såväl deduktiva som induktiva ansatser. Jag har dels konstruerat en analysmodell som baserats på en studie av olika handlingsteorier, ${ }^{3}$ dels gett utrymme för nya handlingsinriktningar att framträda utifrån det empiriska materialet. I den syftesrelaterade textanalysens andra fas, den intertextuella läsningen, jämförs utfallen av de intratextuella läsningarna med varandra för att studera vilka likheter och skillnader som uppstår. Därigenom blir det möjligt att relatera texter, eller delar av texter, till varandra när de ger uttryck för liknande perspektiv. I den intertextuella jämförelsen används även kvantitativa metoder för att tydliggöra hur vanligt förekommande olika handlingsinriktningar är i det empiriska materialet som helhet. Genom att studera vilka gemensamma nämnare och konflikter som finns i och mellan de olika

2. Den analys som presenteras i artikeln är en del av en större helhet. Den ingår i min avhandling Med kränkningen som måttstock. Om planerade bemötanden av främlingsfientliga uttryck i gymnasieskolan (Arneback 2012).

3. Här har jag valt att studera texter av bland annat Judith Butler, Jacques Derrida, Jürgen Habermas, Axel Honneth, Catharine MacKinnon och Nel Noddings i syfte att finna olika sätt att se på handling vid bemötandet av främlingsfientlighet. 
handlingsinriktningarna framträder olika förhållningssätt vid bemötandet av främlingsfientliga uttryck.

Det empiriska materialet består av skolrelaterade lagar, styrdokument och II3 likabehandlingsplaner för gymnasieskolan. De analyserade likabehandlingsplanerna är alla från år 2009 och har valts ut utifrån principen om demografisk spridning med bas i Sveriges Kommuner och Landstings (SKL) kommungruppsindelning. ${ }^{4}$ Likabehandlingsplanerna kommer från 75 kommunalt drivna gymnasieskolor, 4 landstingsägda gymnasieskolor och 34 fristående gymnasieskolor. De har tilldelats ett nummer mellan $\mathrm{I}-\mathrm{II} 3^{5}$ och är anonymiserade; detta förfarande har varit nödvändigt för att få tillträde till flera av de fristående skolornas likabehandlingsplaner eftersom dessa inte är offentliga. De studerade lagarna är skollagen (SFS 1985:I100; SFS 1995:884; SFS 1999:886; SFS 2008:57I), lagen om förbud mot diskriminering och annan kränkande behandling av barn och elever (SFS 2006:67) och diskrimineringslagen (SFS 2008:567). Till detta tillkommer Läroplan för de frivilliga skolformerna (Lpf 94). Innan jag går vidare till artikelns specifika studie kommer jag redogöra för begreppet "främlingsfientlighet" och hur det används i analysen. Som bakgrund väljer jag också att i korthet visa på förekomsten av främlingsfientlighet i skolan.

\section{Bakgrund och begrepp}

Diana Mulinari och Anders Neergaard (20I0) har gjort en fruktbar uppdelning för att förstå två former av rasism när de visar på förekomsten av såväl exkluderande som exploaterande rasism:

Vi kan dels se en exkluderande rasism, vilken skulle kunna benämnas "förlorarnas rasism", som är relaterad till de radikala högerextrema partierna; en rasism

4. De kommuner som ingår är: Arvika, Arvidsjaur, Emmaboda, Eskilstuna, Falkenberg, Hallsberg, Haninge, Hällefors, Hässleholm, Höganäs, Jönköping, Kalix, Krokom, Kungsbacka, Köping, Lidköping, Linköping, Lycksele, Mariestad, Malmö, Mellerud, Mullsjö, Norrtälje, Nybro, Nynäshamn, Oxelösund, Salem, Skövde, Smedjebacken, Sollefteå, Sundbyberg, Sundsvall, Sävsjö, Tierp, Torsby, Upplands Väsby, Varberg, Värmdö, Värnamo, Västervik, Ånge, Älvsbyn, Östersund, Östhammar.

5. I texten kommer jag använda mig av dessa nummer för att referera till planerna, exempelvis står Lbpı3 för likabehandlingsplan I3. 
som dessa partier på många sätt arbetar hårt för att retoriskt distansera sig ifrån. Men vi kan även se en exploaterande rasism, eller en "vinnarnas rasism", vilken är en integrerad del av kapitalismens globala reproduktion och som därmed befinner sig i samhällets centrum (Mulinari \& Neergaard 20I0, s. 68).

Den exkluderande rasismen beskrivs av Neergaard och Mulinari som "förlorarnas rasism”, och den är en tankeströmning som propagerar för att exkludera vissa kulturella grupper från samhället. Företrädarna för denna rasism går ofta att finna i högerextrema kretsar. Neergaard och Mulinari framhåller dock att det vore riskabelt om denna riktning framstod som den enda verksamma rasismen i samhället. Parallellt med förlorarnas rasism finns även en "vinnarnas rasism" som inte uppmärksammas i samma utsträckning. Den står inte på barrikaderna och kräver uteslutning utan livnär sig på att reproducera ett kulturellt förtryck. Denna form av rasism är, enligt Neergaard och Mulinari, snarare exploaterande: den etablerar (föreställningar om) en kulturell över- och underordning i samhället, som skapar värde och fördelar för vissa och nackdelar för andra.

Även om begreppet "rasism" i dag kan ha såväl en biologisk som kulturell förklaringsgrund, associeras det av många med ett biologiskt rasbegrepp (och tillhörande maktrelationer). Denna historiska tyngd har medfört att jag i artikeln använder begreppet "främlingsfientlighet", som signalerar en bredare empirisk ingång. Främlingsfientlighet ska i texten förstås som en fientlighet riktad mot individer, eller grupper av individer, utifrån kulturella faktorer. ${ }^{6}$ Inspirerad av Mulinari och Neergaard väljer jag att här diskutera i termer av en exkluderande respektive exploaterande främlingsfientlighet i skolan. I vilken mån de studerade texterna riktar in sig på att bemöta den exkluderande eller den exploaterande främlingsfientligheten är en empirisk fråga.

Det finns mycket som tyder på att båda formerna av främlingsfientlighet är vanligt förekommande i skolan. I en undersökning genomförd av Skolverket (2002) anger de intervjuade lärarna att det förekommer rasism i var tionde skolklass. Var tionde elev anger också "att det på skolan bärs nazistiska symboler, görs Hitlerhälsningar, sprids rasistiskt eller främlingsfientligt material samt spelas vitmaktmusik" (Skolverket 2002,

6. Se Nationalencyklopedin, http://www.ne.se/lang/fr\%C3\%A4mlingsfientlighet?i_whole_ article=true (hämtad 2I februari 20II). 
s. 20). En rapport från Barnombudsmannen (2008, s. 24 ff.) visar att barn lyfter fram frågor om invandring, integration och rasism som en av de viktigaste frågorna för skolan i dag. Det finns dock en tydlig skillnad i uppfattning bland barnen om vad som är grundproblemet. Hälften av de barn som tar upp frågan har en positiv syn på invandring och ser rasismen som det grundläggande problemet. Den andra hälften anger att det är invandringen i sig som är problematisk. I skolvalet 2oIo fick Sverigedemokraterna I2,8 procent av rösterna och blev därmed fjärde största parti. ${ }^{7}$ Vid en närmare betraktelse är det främst på skolor med en bas av yrkesförberedande program, ofta med manlig dominans, som stödet har ökat radikalt. Denna bild av vilka ungdomar som är benägna att stödja främlingsfientliga partier stämmer väl överrens med flera toleransundersökningar (Forum för levande historia \& Brå 2004, s. 55; Forum för levande historia 20I0, s. 57 ff.). Resultatet pekar på att pojkar i högre grad än flickor ger uttryck för intoleranta åsikter, och att elever på yrkesförberedande program i högre grad än de på studieförberedande program har främlingsfientliga åsikter.

Pojkar uppvisade vid varje jämförelse mindre positiva och mindre toleranta attityder än flickor. Störst var skillnaden mellan pojkar som gick första året på yrkesförberedande program och flickor som gick sista året på gymnasiets studieförberedande program (Forum för levande historia 20I0, s. 64).

Förklaringar till att killar på yrkesförberedande program är överrepresenterade bland de intoleranta går enligt rapporten att finna $\mathrm{i}$ att de har en svag social ställning och känner otrygghet eller alienation. Bilden av den rotlösa och främlingsfientlige unge mannen träder fram. ${ }^{8}$ Denna rotlöshet kan förstås på olika sätt, några möjliga förklaringar går att finna i Paul Willis och Mats Trondmans studier om unga män i arbetarklassen. I Willis (1983, s. Ios ff.) etnografiska studie Fostran till lönearbete framträder en manlig motkultur som genom fientlighet och våld positionerar sig

7. Från http://www.ungdomsstyrelsen.se/art/o,2072,8457,0o.html (hämtad Io oktober 20I0).

8. Även om det finns mönster som visar på vilka grupper som är överrepresenterade i den exkluderande främlingsfientligheten, så är dessa mönster inte entydiga eller absoluta (se Forum för levande historia 20Io). 
gentemot andra grupper (gäller både kön, etnicitet och klass). Studien beskriver vad som sker när arbetarklassens ideal krockar med medelklassens skolkultur, och när ett strukturellt utanförskap skapar en motkultur. Trondman (I995, s. I67 ff.) diskuterar i sin tur framtidsutsikten för arbetarklassens unga män när samhällsomvandlingen bidragit till att efterfrågan på arbete minskat för denna grupp. De unga kvinnorna lämnar oftare bruksorter och söker sig vidare medan männen ofta blir kvar. Trondman ser en fara i att samhället misslyckas med att göra denna grupp delaktig, vilket kan ge allvarliga konsekvenser i framtiden.

Med forskningsresultat av denna karaktär är det lätt att måla upp en bild av vem som är främlingsfientlig i skolan och vilka som är demokratins försvarare. Ett sådant resonemang riskerar dock att leda till en blindhet för att främlingsfientlighet förekommer på olika och samverkande nivåer. För att bredda bilden presenterar jag pedagogisk forskning som beskriver hur skolan tenderar att reproducera en exploaterande främlingsfientlighet som underordnar minoritetskulturer. En bidragande orsak till detta är förekomsten av en monokulturell förståelse i utbildningssammanhang där den normerande svenskheten skapar en uppdelning mellan "vi" och "dem", där barn och unga med utländsk bakgrund beskrivs som avvikande (Tesfahuney 1999, s. 65 ff.; León 200I, s. I6 ff.; 20I0, s. 3I ff.; Runfors 2003, s. 2II ff.; Gruber 2008, s. I69 f.). För att bryta denna maktordning måste man enligt René León bryta uppdelningen mellan svenskar och invandrare för att i stället

bejaka de identitetsmarkörer som hittills skapat deras annorlundahet (såsom modersmål, religiös tillhörighet, historia, föräldrarna). Ett sätt är att ta in det annorlunda i skolans ordinarie verksamhet och sociala liv, att ge det legitimitet i skolans värld. Det vill säga, att göra det annorlunda normalt (León 200I, s. $2 \mathrm{I}-22)$.

Mekonnen Tesfahuney (I999, s. 79 f.) kommer till en liknande slutsats: skolan har länge vilat på monokulturella föreställningar som måste utmanas. Men denna kamp kan aldrig ensidigt bedrivas i skolan utan måste förenas med liknande processer i övriga samhället (inom exempelvis universitet, medier och andra institutioner). Skolan kan utgöra en viktig beståndsdel i en förändring men kan aldrig ensam vrida samhället bortom 
monokulturella föreställningar. Det ömsesidiga förhållandet mellan samhälle och utbildning medför att skolan lätt anammar föreställningar som dominerar i samhället (jfr Bourdieu \& Passeron 2008 [1970], s. 245 ff.). I det här fallet finns det en risk för att den exploaterande främlingsfientligheten återskapas i skolan.

Tidigare forskning visar på att såväl exkluderande som exploaterande främlingsfientlighet förekommer i skolan. I skenet av den förekomsten uppstår frågan om hur främlingsfientlighet kan bemötas i skolan.

\section{Tre förhållningssätt vid bemötandet av främlingsfientlighet i skolan}

Frågan om bemötandet av främlingsfientlighet har sedan 1994 successivt fokuserats alltmer. Under den studerade tidsperioden framträder tre olika former av förhållningssätt till frågan om bemötandet av främlingsfientliga uttryck i skolan. Det decentraliserade etiska ansvaret är framträdande under åren 1994-2006. Därefter får frågan en utförligare lagstiftning att förhålla sig till vilket bidrar till att förhållningssättet att förebygga och förhindra kränkningar därefter dominerar. Denna logik är dock utmanad av förhållningssättet att förhindra främlingsfientlighet (utifrån en bedömning av uttryckens karaktär). Inledningsvis presenterar och beskriver jag de olika förhållningssätten för att därefter i en jämförande analys studera dem i skenet av varandra.

\section{Decentraliserat etiskt ansvar}

Fram till 2006 fanns få riktlinjer för skolan att luta sig emot för att få vägledning om hur främlingsfientliga uttryck skulle bemötas. Det problemområde som dessförinnan krävt ett planlagt arbete var, sedan slutet av I960-talet, mobbningsfrågan (Landahl 2006, s. 87 ff.; Nordgren 2009, s. 44 ff.). Frågan om främlingsfientliga uttryck var länge osynlig i policydokument för skolan. Först på 90-talet kom frågan på allvar upp på agendan, nu börjar det produceras forskning och skolverksrapporter som visar på förekomsten av främlingsfientlighet i skolan.

Det är också vid denna tid som de första handlingsinriktade rekommendationerna formuleras. I läroplanen från 1994 står det att läsa: "Främ- 
lingsfientlighet och intolerans måste bemötas med kunskap, öppen diskussion och aktiva insatser" (Lpf 94, s. 23). Handlingsinriktningen är tredelad och relativt vag. Här finns en tanke om att främlingsfientlighet går att förhindra genom att man skapar förutsättningar för kunskapsutveckling och diskussion. Vid mitten av 1990-talet införs i skollagen meningar som påvisar vikten av att agera mot kränkande behandling (SFS 1995:884). Några år senare skrivs rasism in som ett exempel på vad som är kränkande. Skolan får då till ansvar att "aktivt motverka alla former av kränkande behandling såsom mobbning och rasistiska beteenden" (SFS I999:886, I kap. $2 \$$ ). Under 90-talets andra hälft är det således fastslaget att skolor har till uppgift att aktivt bemöta främlingsfientliga uttryck. Samtidigt finns lite att hämta om hur detta bemötande ska gå till, vilket ger stort tolkningsutrymme till den lokala nivån. Ett sådant förhållande mellan den nationella och lokala nivån väljer jag att benämna "decentraliserat etiskt ansvar”. Här är det upp till varje lärare, och i vissa fall varje skola eller kommun, att förhålla sig till hur detta etiska ansvar ska bäras upp. Det samma gäller för definitionen av vem och vad som är främlingsfientlig och främlingsfientligt. I en modell med stort friutrymme uppstår två möjliga förfaranden: I) att på förhand definiera hur detta frirum ska hanteras, eller 2) att förhålla sig till det etiska ansvaret som odefinierat och agera i den unika situationen.

När det decentraliserade ansvaret definieras på förhand, blir det dessa riktlinjer som ska vägleda skolan och läraren vid bemötandet av främlingsfientliga uttryck i skolan. Exakt hur dessa strategier såg ut och formerades är relativt obeforskat. Men att tillvägagångssätten var skiftande och saknade ett gemensamt nav är dock möjligt att konstatera genom att jämföra några lokala planer från denna tid (Arneback 2008, s. 8 ff.). Här finns lokalt utformade dokument som tydligt definierar den främlingsfientlige som högerextrem och skapar listor för vad som kännetecknar denna rörelse. Parallellt förekommer dokument som betonar betydelsen av att vara öppen för vad som kan vara främlingsfientligt och enbart formulerar ideal som skolan har till uppgift att sträva gentemot. Såväl yttrandefrihetens gränser som definitionen av vad som är främlingsfientligt blir i ett sådant förhållningssätt förbundet med de specifika riktlinjer som formulerats på den lokala nivån. 
Ett annat möjligt förfarande i detta friutrymme är att låta det etiska ansvaret vara odefinierat och i stället avgöra hur främlingsfientliga uttryck ska bemötas i den unika situationen. Ett sådant förhållningssätt till främlingsfientlighet och yttrandefrihet i skolan har förespråkats av den pedagogiska filosofen Jim Garrison (2004, s. 94 ff.). Han menar att betydelsen av att vara i mötet människor emellan är betydligt viktigare än att skapa skarpa riktlinjer för mellanmänskliga möten i förväg. Genom att skapa rum för sårbarhet kan läraren skapa förutsättningar för utveckling och genuina dialoger.

Lärare som undervisar på detta sätt kommer att uppleva större svårigheter med att deras personliga identitet utvecklas (och även fragmenteras), men de är också de som är mest benägna att förebygga farorna med demokratiska dialoger som berör skillnader och att tillsammans skapa den säkraste, dock inte sterila, utbildningssituationen (Garrison 2004, s. 94, min övers.).

I ett sådant perspektiv är det just öppenheten som är grunden för att skapa pedagogiska och genuina möten mellan människor. Yttrandefrihetens gränser blir därigenom odefinierade eftersom de bara kan avgöras i den unika situationen. Det leder också till en öppenhet för vad som är främlingsfientligt. I stället för att på förhand definiera främlingsfientlighet gäller det att vara närvarande, sårbar och inkännande.

Hur förhållandet mellan de definierade och odefinierade förhållningssätten såg ut under denna tid och vilken rikedom som fanns när det gäller olika sätt att se på frågan, är utifrån denna studie inte möjligt att besvara. Vad vi kan säga är att tiden före 2006 innehöll ett stort mått av lokal frihet och variation.

\section{Förebygga och förhindra kränkningar}

I och med den lagstiftning som trädde i kraft I april 2006, lagen om förbud mot diskriminering och annan kränkande behandling av barn och elever (SFS 2006:67), fick bemötandet av främlingsfientliga uttryck i skolan en ny och tydligare inramning. I regeringens proposition (Prop. 2005/06:38), som föregick lagen, framgår att den syftar till att ge alla elever lika rättigheter samt att motverka diskriminering baserat på kön, etnisk tillhörighet, religion, sexuell läggning, funktionshinder samt annan kränkande 
behandling. Lagen är unik på så sätt att den ger ett juridiskt ansvar till skolan som är förbundet med eventuella sanktioner vid bristande ansvarstagande. Den för också samman begreppen diskriminering, trakasserier och kränkande behandling på ett sätt som tidigare inte varit rådande i skolan. Sedan januari 2009 går lagrummet att finna i diskrimineringslagen (SFS 2008:567) och i den reviderade skollagen (SFS 2008:571, I4 a kap.); efter sommaren $201 \mathrm{I}$ i den nya skollagen (SFS 20I0:800). Diskrimineringslagen gör begreppslig skillnad mellan kränkning och trakasserier, det senare är en kränkning som är förbunden med någon av diskrimineringsgrunderna, exempelvis etnicitet eller religion. Jag kommer fortsättningsvis att använda mig av begreppet kränkning även för det som juridiskt benämns som trakasserier.

Det vanligaste förhållningssättet vid bemötandet av främlingsfientlighet i de analyserade likabehandlingsplanerna är att förebygga och förhindra kränkningar. Att så är fallet är inte förvånande eftersom det är ett förfarande som följer de nämnda lagarnas utformning. Genom att definiera det otillåtna sätts gränsen för det tillåtna.

Enligt lagen 2006:67 om förbud mot diskriminering och annan kränkande behandling är det förbjudet att särbehandla eller kränka någon elev inom gymnasiet eller vuxenutbildningen på grund av kön, etnisk tillhörighet, religion eller annan trosuppfattning, sexuell läggning eller funktionshinder (Lbp2o; Lbp2I).

Med kränkande särbehandling avses återkommande klandervärda eller negativt präglade handlingar som riktas mot enskilda personer, såväl elever som personal, på ett kränkande sätt och som kan leda till att dessa ställs utanför arbetsplatsens/ skolans gemenskap (Lbp8I).

Det otillåtna definieras genom att klargöra att handlingar som bidrar till att någon blir kränkt ska förhindras. Det är alltså konsekvensen av en handling som avgör hur den ska bemötas. Bemötandet som ska komma till stånd är tredelat: skolorna får till ansvar att arbeta främjande, förebyggande och förhindrande (SFS 2008:567, 3 kap.; Skolverket 2009, s. IO; Rimsten 20I0, s. 89). Analysen av likabehandlingsplanerna visar dock att det är mycket ovanligt att skolorna utvecklar riktlinjer för ett främjande arbete i planerna. Däremot har nästan alla planer formulerat handlingsinriktningar för det förebyggande och förhindrande arbetet. 
Det förebyggande arbetet i likabehandlingsplanerna ser ut på många olika sätt. Jag väljer här att lyfta fram de fem vanligaste handlingsinriktningarna i likabehandlingsplanernas förebyggande arbete (de förekommer i mellan 47 till ıo4 planer). Vissa av planerna förespråkar alla handlingsinriktningarna, andra ingen och det förekommer inte något spänningsförhållande dem emellan. De framstår snarare som rätter på ett smörgåsbord, ofta med ursprung i läroplanen, som skolan har valt att anamma eller förkasta.

Den handlingsinriktning som förekommer mest frekvent är att skapa metoder för att upptäcka kränkningar på skolan. Här förespråkas enkäter, samtal och observationer för att komma till rätta med problemet.

Skolan skall kontinuerligt kartlägga och observera den egna verksamheten och skaffa kunskap om den aktuella situationen genom individuella samtal med samtliga elever, klassråd, elevskyddsombud och samplaneringsdagar (Lbpзo).

Då skolans pedagoger arbetar tillsammans med eleverna i olika grupper och situationer samt äter lunch tillsammans, finns förutsättningar att skapa en god bild av elevens sociala utveckling liksom tillfällen att stävja samt arbeta med icke önskvärda attityder och beteenden (Lbp47).

Ofta föreskrivs att detta arbete ska leda fram till väl avvägda bedömningar av huruvida (risk för) kränkningar förekommer. Målet är att få en bättre bild av verksamheten för ett skapa ett underlag för vidare handlingar. En annan vanligt förekommande handlingsinriktning är att förespråka prövande kommunikation där eleverna får möjlighet att samtala och reflektera över sina värderingar tillsammans med en pedagog:

Återkommande diskussioner om etik, moral, människors värde, jämställdhet mellan könen, relationer och demokratins grunder genomförs i kurser som svenska, religion och samhällskunskap. Dessa diskussioner äger naturligtvis även rum i form av personliga samtal mellan elever och personal (Lbp33).

Genom att samtala med varandra i undervisningen och vid personliga samtal skapas förutsättningar för utveckling. "Kunskap och löpande samtal och diskussioner är viktiga inslag för att öka förståelsen för varandra som människor och hur olikheter utmanar och utvecklar givna 
mönster" (Lbp44). En annan pedagogisk handlingsinriktning är att förespråka kunskapsgenererande handlingar. Dessa handlingar riktas både mot elever och personal och påvisar behovet av utbildning och fortbildning. "Skolledningen ansvarar för att elever och personal regelbundet utbildas i frågor som mobbning, trakasserier, kränkande särbehandling, rasism, främlingsfientlighet och diskriminering” (Lbp33). Den grundläggande tanken här är att kunskap skapar förutsättningar för att bemöta främlingsfientlighet, samtidigt som det minskar risken för att främlingsfientlighet uppstår.

Planerna lyfter också fram behovet av samhörighetsbildande handlingar på skolan, utifrån argumentationen att den som känner gemenskap inte kränker. Sociala aktiviteter och pedagogiska strategier förespråkas för att se till att ingen blir utanför.

Återkommande aktiviteter för att behålla och utveckla trivseln hela skoltiden genomförs. Ex: gemensamma aktiviteter på friluftsdagar, laga mat tillsammans. Läraren ansvarar för gruppindelning i klassen och att ser till att grupperna varieras så att eleverna lär känna varandra och är trygga med att få en plats i en grupp (Lbp23).

Andra planer lyfter fram behovet av skolgemensamma aktiviteter för att skapa en skolanda som verkar förebyggande. "Projekt/teman där samarbete mellan elever över klassgränser genomförs för att öka sammanhållningen och respekten mellan elever och program” (Lbp82). Den sista handlingsinriktningen som presenteras här är förespråkandet av information. Genom att sprida innehållet i planen på skolan ska de som berörs av planen få kännedom om den samma:

Inför varje läsårsstart ges skriftlig och muntlig information till elever, personal samt föräldrar beträffande skolans rutiner, riktlinjer och vem man kan vända sig till vid mobbning, trakasserier och annan kränkande särbehandling (Lbp33).

Genom denna information ska de föreskrivna handlingarna slå igenom i verksamheten. Om det förebyggande arbetet innehåller många olika handlingsinriktningar ser det annorlunda ut när det gäller det förhindrande arbetet. $\mathrm{Om}$ någon blir kränkt ska skolan gå från ett mångfasetterat förebyggande arbete till en åtgärdande handlingsplan som ofta är 
instrumentellt upplagd (jfr Landahl 2006, s. I2I ff.). Arbetet skrivs ofta fram som punktlistor som anger hur skolan ska agera, vem som ska agera och kontaktas, vilka samtal som ska komma till stånd och hur det ska dokumenteras och följas upp. Samtalen som förespråkas är ofta utredande och åtgärdande, och det är vanligt att tidigare mobbningsplaner får ligga till grund för hur denna process ska gå till. De utredande samtalen syftar till att ta reda på vad som hänt, medan de åtgärdande samtalen handlar om att få bukt med problemet.

Utredningen ska syfta till att få reda på kränkningens karaktär och ska sedan ligga till grund för vilka åtgärder som ska vidtas [...] Åtgärder ska spegla kränkningens karaktär och omfattning. En kränkning ska inte göras mindre eller större än den är. Åtgärder utformas av elevhälsoteamet i samråd med berörd skolpersonal, den kränkte eleven, den/de som kränkt samt vårdnadshavare (Lbpı2).

Exemplet ovan beskriver att flera parter ska vara delaktiga i utformandet av åtgärder. Det är dock vanligt med en förmanande ingång där den elev som kränkt tillrättavisas och i vissa fall anmäls. "För de fall när kränkningar fortsätter eller är av allvarlig natur vidtas disciplinära åtgärder. I varje enskilt fall övervägs om anmälan till socialtjänsten, polisen och/eller arbetsmiljöverket ska göras” (Lbpiz). I flertalet planer finns en öppenhet för att alla som verkar på skolan, elev såväl som personal, kan vara den som kränker, men det finns också planer som tar för givet att kränkningar sker mellan elever eftersom de vuxna inte skrivs fram som möjliga aktörer.

Även om de enskilda personalledda samtalen dominerar som samtalsform i det förhindrande arbetet, så finns det även planer som lyfter fram möjligheten att vid mindre allvarliga kränkningar försöka få till stånd en prövande kommunikation mellan de inblandade parterna. Detta kallas medlingssamtal och förespråkas enbart om den som blivit kränkt så önskar.

Om den kränkte vill, kan medlingssamtal genomföras. Då ska samtalet alltid avslutas med att ett beteendeavtal skrivs. [...] Ett beteendeavtal kan användas i vissa situationer. Hur ska den kränkte eleven och den/de som kränkt förhålla sig till varandra? Den kränkte eleven och den/de som kränkt bestämmer själva hur avtalet ska se ut och fungera (Lbpi2; Lbp24). 
Skillnaden är att ansvaret för samtalsprocessen delvis flyttas från personal till de inblandade parterna. Även om denna samtalsform har samma syfte som det åtgärdande samtalet, att komma till rätta med kränkningar, finns här en tilltro till att samtal mellan de berörda kan skapa goda lösningsförslag.

Det förhindrande arbetet innehåller även, i närmare 30 fall, förespråkandet av omsorgspraktiserande handlingar som syftar till att stötta den elev som blivit utsatt för kränkningar. "Den person som utsatts för rasism, främlingsfientlighet eller diskriminering erbjuds stödjande samtal hos kurator på skolan. Även stödjande samtal med föräldrar kan vara aktuellt" (Lbp33). I några fall anges att detta erbjudande även ska ges till den som kränkt. Syftet med dessa samtal är att arbeta med frågor om självförtroende (gentemot den kränkta), självreflektion (gentemot den som kränkt) och att finnas till hands i en konfliktfylld situation.

I förhållningssättet att förebygga och förhindra kränkningar finns en stor öppenhet för olika handlingsinriktningar gentemot främlingsfientliga uttryck som inte upplevs som kränkande. I det förebyggande arbetet förespråkas exempelvis prövande kommunikation och samhörighetsbildande handlingar för att bemöta främlingsfientliga uttryck. När något anses vara kränkande är det dock skäl för att förhindra att det ges fortsatt utrymme. En sådan pedagogisk strategi har förespråkats av Barbara Applebaum (2003, s. 156 ff.; 2008, s. 239 ff.) som menar att det är viktigt att i pedagogiska sammanhang förhindra ord som sårar. Hon menar att det är förödande för enskilda individer och att det riskerar att reproducera en orättvis maktordning. Om yttrandefrihetens gränser definieras med kränkningen eller sårandet som vägledande princip, måste bedömningens fokus ligga på det enskilda uttryckets konsekvenser. "Med andra ord är det effekterna av tillmälen som avgör dess kränkande konsekvens och det hör samman med vem som säger vad och hur till vem" (Skolverket 2007, s. 13). Att betydelsen av ett uttryck måste förstås i sin specifika kontext har bland annat lyfts fram av Rickard Jonsson (2007). Genom en etnografisk studie vid en högstadieskola visar han att betydelsen och konsekvensen av ordet "blatte" inte går att förutbestämma. I stället måste uttrycket bedömas i sitt specifika sammanhang, bedömningen behöver vara kontextuell. Det är till exempel av avgörande 
betydelse vilken kategoritillhörighet ("svensk" eller "invandrare") personer som uttalar ordet har.

När det gäller bedömningen av kränkningar finns olika idéer om hur kränkningar ska uppdagas. Här finns planer som skriver fram att det förhindrande arbetet ska ta vid när en elev anmäler kränkningen. ”När en elev berättar att hon/han blivit utsatt för diskriminering eller annan kränkande behandling ska skolan utreda och förhindra fortsatt kränkning" (Lbp6I). Andra planer betonar betydelsen av att personalen måste känna in vad som sker för att komma åt kränkningar som inte anmäls.

Som anställd ska du vara lyhörd för vad som händer på skolan. Att vara lyhörd innebär att Du reagerar även på små signaler. Om det förekommer kränkningar behöver det inte innebära att en elev berättar vad som hänt och hur man upplevt en viss situation (Lbp4I).

Det medför att frågan om yttrandefrihetens gränser alltmer har kommit att handla om att skapa förutsättningar för att göra kontextuella bedömningar av vad som är eller kan vara kränkande. För att därefter agera utifrån en sådan bedömning.

Om bedömningen ska fokusera på ett uttalandes konsekvens, medför det att behovet av att definiera vad som är främlingsfientlighet, högerextremism, rasism eller nazism blir mindre intressant. Att definiera sådana innebörder ger inte vägledning för principen, utan kan snarare motverka öppenheten för mångfalden av uttryck som kan medföra en kränkande konsekvens. Frågan om vem som utövar makt och förtryck har därför inget på förhand givet svar. Även om så är fallet går det att konstatera att flertalet av de handlingar som förespråkas i det förebyggande arbetet riktar in sig på att arbeta med elevernas utveckling. Det tyder på att det finns en uppfattning om att det är där det eventuella problemet föreligger. Eleverna behöver kartläggas och utredas, få diskutera och vara en del av en gemenskap. När det gäller personalen är det framför allt behovet av fortbildning som lyfts fram. Men det finns också några mindre framträdande handlingsinriktningar som vänder blicken mot skolan. I tolv planer lyfts behovet av att agera strukturanalyserande fram, vilket handlar om att studera om skolan som institution bidrar till att skapa ojämlika villkor. 
Det är viktigt att förebygga och upptäcka strukturell kränkning av alla slag som skolan skulle kunna göra sig skyldig till. Därför förs en kontinuerlig diskussion i personalgruppen och tillsammans med elevråd om hur skolan organiseras (Lbp94).

Det finns också ett förespråkande av normkritiska handlingar i ett tiotal planer. I dessa planer får skolan till ansvar att se över sitt agerande och undervisningens innehåll för att förhindra att skolan förmedlar enfald före mångfald.

Litteratur och annat undervisningsmaterial granskas så att de inte innehåller diskriminerande text eller bilder. Den ska även vara allsidig och visa på en mångfacetterad bild av samhället och t.ex. inte endast förmedla en bild utifrån heterosexuella, svenska, manliga och/eller kristna normer (Lbp4I).

Skolan har ett aktivt förhållningssätt som innebär att vi avsätter minst en arbetslagsträff per läsår till att ifrågasätta och reflektera över de normer och värderingar som skolan förmedlar, genom sin organisation och undervisning (Lbp84).

Även om lagen inte anger något om vem som kränker, finns i de lokala likabehandlingsplanerna en tendens att i första hand se eleven som den potentiella förövaren. Inte minst i det förebyggande arbetet som så tydligt fokuserar eleverna, och i så liten grad vänder blicken mot lärarna och skolan som organisation. Det förhindrande arbetet inkluderar oftast personalen som möjliga gärningsmän, men skolan är fortsatt frånvarande. Utifrån detta resultat menar jag att det finns en tendens att skolorna i högre grad fokuserar på den exkluderande främlingsfientligheten som uttrycks av en enskild individ (oftast en förmodad elev) än den exploaterande främlingsfientligheten som kan finnas inbäddad i institutionens strukturer.

\section{Förhindra främlingsfientlighet}

Även om att "förebygga och förhindra kränkningar" tenderar att dominera såväl lagrum som de lokala planerna, så förekommer parallellt förespråkandet av ett annat förhållningssätt vid bemötandet av främlingsfientlighet. Detta förhållningssätt bedömer inte konsekvensen av ett uttalande, utan argumenterar för att vissa uttryck kan förbjudas på för- 
hand, av principiella skäl och/eller med hänvisning till den meningsbärande kontext som det vanligtvis och i första hand uttrycks i. Yttrandefrihetens gränser blir här förbundet med en principiell bedömning av uttryckets karaktär. Om något bedöms vara rasistiskt eller främlingsfientligt är det skäl nog för att förhindra förekomsten av sådana uttryck. Det är intressant att de planer som antar ett sådant förhållningssätt gör det enbart i frågor som berör främlingsfientlighet och rasism. Det finns inte samma benägenhet att skriva fram att exempelvis alla homofobiska uttryck ska förbjudas på förhand.

På vårt gymnasium accepteras inga rasistiska, främlingsfientliga eller andra kränkande symboler, inte heller någon musik med ett sådant budskap. Vid spridning av rasistiskt, främlingsfientligt eller annat diskriminerande material såsom t ex flygblad eller affischer har all personal på skolan ansvar att genast stoppa denna spridning. Skolledningen ska därefter snarast informeras om materialet och om vem som spridit detta.

Om någon på skolan bär rasistiska, främlingsfientliga eller andra diskriminerande symboler eller spelar musik med samma budskap är det personalens skyldighet att säga till personen att detta inte är tillåtet och rapportera till skolledningen som beslutar om eventuella fortsatta åtgärder som $\mathrm{t}$ ex polisanmälan. Personalen på skolan ska ingripa om någon använder skällsord med rasistiska, främlingsfientliga eller diskriminerande innebörd (Lbp33; Lbp49; Lbp6o).

I ett förhållningssätt som fokuserar på uttryckets karaktär går det att på förhand avgöra vilken typ av uttalanden och symboler som inte ska ges tillträde i skolan. Detta förhållningssätt kan antingen ses som grundläggande princip som varje enskild individ får till uppgift att göra sina bedömningar utifrån. Eller så ges en förteckning över vilka symboler som avses, ofta innehållande högerextrema symboler och vitmaktmusik. Dessa listor infogas oftast inte i planerna, utan personalen hänvisas till vart denna information går att hämta. Nedanför ges först ett exempel på hur denna hänvisning kan göras. Därefter visar jag på hur det kan se ut när planerna i sig själv anger vilka oönskade uttryck som inte får förekomma:

Vid spridning av rasistiskt, främlingsfientligt eller annat diskriminerande material som t ex affischering eller lappar, urklipp med nazistiska symboler, kläder 
eller märken som ger rasistiska signaler eller anses riskera att störa ordningen i skolan, ansvarar skolan för att genast stoppa detta. Folder med urval av symboler finns hos varje rektor samt hos skolkurator (Lbp86).

All skolpersonal ska vid rasistiska tillmälen och tendenser reagera genom att tydliggöra att rasistiska åsikter inte är förenliga med skolans värdegrund. Ord som i dagens läge uppfattas som rasistiska, inte är politiskt korrekta och som självklart inte får förekomma är t.ex. "neger", "svarting", "blatte" och "finnjävel" (Lbp24).

Vid de tillfällen som detta förhållningssätt framträder finns det alltid parallellt med att "förhindra och förebygga kränkningar" i likabehandlingsplanerna. Dubbeltydigheten som därmed uppstår medför ett spänningsförhållande där olika bedömningsprinciper ställs emot varandra. Om vi ställer uttryckets karaktär i centrum för vår bedömning uppstår en annan gränsdragning gentemot främlingsfientliga uttryck. Bedömningen blir här förenlig med frågan om vilka uttryck som är att betrakta som främlingsfientliga och som därmed ska förhindras. Det ger ofta en snävare bedömning av vad som går att samtala om i skolan. De uttalanden som tidigare hade kunna bli föremål för en prövande kommunikation, i ett förebyggande arbete, ska enligt detta förhållningssätt förhindras om det bedöms vara främlingsfientligt. Bedömningen går därmed från att vara kontextuell (utifrån kränkningen) till att bli principiell (utifrån uttalandets karaktär). Frågan om vem och vad som är främlingsfientlig och främlingsfientligt ställs här på sin spets eftersom det blir huvudfrågan. I de planer där förteckningar förekommer blir det tydligt att det är en exkluderande främlingsfientlighet som fokuseras, ofta med högerextrema kopplingar.

\section{En jämförande analys}

Artikeln har presenterat tre förhållningssätt till främlingsfientliga uttryck i skolan genom att studera vilka handlingar som förespråkas och hur de förhåller sig till yttrandefrihetens gränser och vem eller vad som pekas ut som främlingsfientlig eller främlingsfientligt. Sammanfattningsvis framträder följande mönster: 
ARKIV | NR 2 | DET VITA FÄLTET II

\begin{tabular}{|c|c|c|c|}
\hline FÖRHÅLLNINGSSÄTT & $\begin{array}{l}\text { HANDLINGS- } \\
\text { INRIKTNING }\end{array}$ & $\begin{array}{l}\text { YTTRANDEFRIHETENS } \\
\text { GRÄNS }\end{array}$ & $\begin{array}{l}\text { GENTEMOT VEM } \\
\text { ELLER VAD? }\end{array}$ \\
\hline $\begin{array}{l}\text { Decentraliserat etiskt } \\
\text { ansvar (före 2006) }\end{array}$ & $\begin{array}{l}\text { a. Lokal eller } \\
\text { personlig } \\
\text { b. Rörlig }\end{array}$ & $\begin{array}{l}\text { a. Lokalt eller } \\
\text { personligt definierad } \\
\text { b. Odefinierad }\end{array}$ & $\begin{array}{l}\text { a. Lokalt eller } \\
\text { personligt definierat } \\
\text { b. Odefinierat }\end{array}$ \\
\hline $\begin{array}{l}\text { Förebygga och för- } \\
\text { hindra kränkningar }\end{array}$ & $\begin{array}{l}\text { Förebyggande } \\
\text { och förhindrande }\end{array}$ & $\begin{array}{l}\text { Uttryckets konse- } \\
\text { kvens (kontextuell } \\
\text { bedömning) }\end{array}$ & $\begin{array}{l}\text { Den eller det } \\
\text { som kränker eller } \\
\text { diskriminerar }\end{array}$ \\
\hline $\begin{array}{l}\text { Förhindra } \\
\text { främlingsfientlighet }\end{array}$ & Förhindrande & $\begin{array}{l}\text { Uttryckets karak- } \\
\text { tär (principiell } \\
\text { bedömning) }\end{array}$ & $\begin{array}{l}\text { Den eller det som är } \\
\text { främlingsfientlig eller } \\
\text { främlingsfientligt }\end{array}$ \\
\hline
\end{tabular}

Det är uppenbart att det finns spänningar och konflikter i synen på bemötandet av främlingsfientlighet i skolan. Jag kommer här att lyfta fram två konflikter som uppstår mellan dessa olika synsätt. I. Vem som ska definiera hur främlingsfientlighet ska bemötas (spänningen mellan nationellt, lokalt och personligt formuleringsutrymme). 2. Hur yttrandefrihetens gränser och den främlingsfientlige eller det främlingsfientliga ska definieras (spänningen mellan olika bedömningsgrunder).

\section{Från moraliskt till juridiskt ansvarstagade på lokal nivå}

I de tre förhållningssätten finns olika synsätt på vem som ges ansvaret att bestämma vilket bemötande som ska komma till stånd och på vilka grunder. I förhållningssättet "förebygga och förhindra kränkningar" formuleras en princip på nationell juridisk nivå som personalen har till ansvar att utveckla och följa på lokal nivå. I vissa fall utvecklas på den lokala nivån riktlinjer som är snävare än de nationella riktlinjerna, genom att det förordas ett förhindrande av främlingsfientlighet utifrån uttryckets karaktär. De två förhållningssätten erbjuder en grund att överväga sina handlingar utifrån. Det decentraliserade etiska ansvaret som dominerade fram till 2006 har en annan syn på vem som ska formulera principen för bemötandet. Här ges formuleringsansvaret i större utsträckning till den lokala nivån, vilket kan ge utrymme för personliga val. 
Förskjutningen över tid har gått från ett decentraliserat etiskt ansvar, med stort lokalt formuleringsutrymme, till nationella juridiska principer som ska omsättas och bäras upp av den lokala nivån. Denna förskjutning kan beskrivas som en rörelse från ett moraliskt ansvarstagande till ett juridiskt ansvarstagande (jfr Nordgren 2009, s. 45 ff.). En kritisk fråga som kan riktas mot en sådan uppdelning är om det moraliska ansvaret behöver stå i kontrast till det juridiska ansvaret. På ett sätt är uppbärandet av en princip alltid förbundet med ett enskilt moraliskt ansvar, oavsett vem som formulerat principen, eftersom det bär med sig ett tydligt uppdrag för den enskilda personen att hantera. Det är dock inte detsamma att följa en fastställd princip som att fritt formulera sina egna bedömningsgrunder eller att i varje stund avväga olika handlingsmöjligheter. Genom den starkare juridiska regleringen (sedan 2006) har läraren fått tydligare riktlinjer som gör att frågan fått en starkare position, samtidigt har läraren i hög grad förlorat utrymmet att själv avgöra handlingsinriktning. De moraliska bedömningarna och de handlingar som följer därpå måste förenas med de juridiska direktiven. Moralen i skolan blir juridiskt bestämd, vilket möjliggör vissa handlingsinriktningar och omöjliggör andra. Bemötandet av främlingsfientlighet har därmed blivit både tydligare och mer inrutat.

\section{Olika bedömningsgrunder skapar spänningar}

De tre förhållningssätten som presenteras har olika syn på hur yttrandefrihetens gränser ska definieras och i vilken mån den främlingsfientlige och främlingsfientlighet kan definieras i förväg. Förhållningssättet "förhindra främlingsfientlighet" definierar i högre grad än de andra dessa relationer på förhand. Det som är främlingsfientligt ska förbjudas i sig, oberoende av om det drabbar en konkret individ. Uttalanden som bedöms vara främlingsfientliga är inte tillåtna på skolan och markerar en gräns för vad som får yttras. I de likabehandlingsplaner som analyserats finns flera exempel på skolor som i frågan om främlingsfientlighet väljer att hänvisa till listor med symboler, musik eller uttryck som är främlingsfientliga, och anger att dessa inte får förekomma på skolan. Det är också tydligt att de planer som antar ett sådant förhållningssätt i hög grad fokuserar en exkluderande främlingsfientlighet med högerextrem anknytning. 
Den förmodat främlingsfientlige går också att placera in i ett sådant ramverk. Samtidigt som dessa listor ger en kunskap om olika uttrycks härkomst och innebörder, ger de också en specificering av vem och vad som är främlingsfientlig och främlingsfientligt. Därigenom finns en risk för en enögdhet där den tänkta förtryckaren är på förhand given och där andra former av förtryck blir osynliggjort (exempelvis minoritetsgrupper som förtrycker minoritetsgrupper eller institutionella främlingsfientliga uttryck av exploaterande karaktär). Samtidigt finns det också planer som inte anger riktlinjer för vad denna främlingsfientlighet är, utan nöjer sig med att konstatera att det som är främlingsfientligt inte är tillåtet. Ett sådant förfarande ger en större öppning för att se olika former av förtryck.

Det dominerande förhållningssättet sedan 2006 är att "förebygga och förhindra kränkningar”, vilket också bärs upp av skolrelaterade lagar och av läroplanen. Här har dokumenten på förhand definierat vilka konsekvenser som är oönskade, vilket leder fram till att diskriminering, trakasserier och kränkningar kommer i förgrunden. För att arbeta mot handlingar som leder till att sådana konsekvenser uppstår ska alla skolor arbeta främjande, förebyggande och förhindrande. Detta ramverk medför att den främlingsfientlige och främlingsfientlighet inte definieras närmare. I stället är det konsekvensen av en handling som avgör vilken respons som är möjlig. Om någon blir kränkt ska skolan gå från att förebygga att det kunnat ske, till att förhindra att det som skett ska få fortskrida.

I ett flertal planer framträder synsätten att bedöma uttrycken i sig (principiell bedömning) och att bedöma konsekvenserna av handlingar (kontextuell bedömning) sida vid sida. Den dominerande principen i planerna är att fokusera på handlingars konsekvenser, samtidigt som vissa former av uttalanden definieras som otillåtna i sig. Detta är motsägelsefullt eftersom förhållningssätten har olika sätt att förhålla sig till yttrandefrihet i skolan; fokus på konsekvensen eller innebörden hos ett uttryck för med sig olika tidsperspektiv. Med konsekvensen i fokus är det i nuet som ett uttryck kan bedömas, medan en bedömning av vilka uttryck som är otillåtna går att göra i förväg. Det ger också olika förhållningssätt till huruvida det i förväg går att definiera vem som är rasist eller främlingsfientlig och vad som är rasism eller främlingsfientlighet. Spänningen som finns i flera likabehandlingsplaner är såldes om det som är främlingsfientligt 
(principiellt) eller det som blir främlingsfientligt (kontextuellt) ska utgöra underlag för den förhindrande principen. Denna dubbelhet blev tydlig i den diskussion som förts i många skolor om Nationaldemokraterna ska ges tillträde till skolors offentliga rum och sprida politisk propaganda. Justitiekanslern (2008) har i en omdiskuterad bedömning yttrat sig om att det inte går att på förhand utesluta någon att delta på grund av dennes åsikter. Om skolorna ska slå fast en princip för politiska partiers tillträde till skolan ska samma princip gälla för alla partier. Konsekvenserna av ett besök kan dock medföra att en förhindrande princip kan träda in: ”Om åsikter förs fram som uttrycker missaktning för andra elever eller personal, exempelvis trakasserier eller andra kränkningar, är skolledningen och skolans personal skyldiga att agera" (Skolverket 20I0, s. I8). Bedömningen som JK gör visar på att det är den kontextuella bedömningen som är den gällande principen och att den principiella bedömningen kan hamna i konflikt med yttrandefriheten.

Ett tredje förhållningssätt, som var möjligt innan 2006 men som inte är framträdande i de studerade likabehandlingsplanerna, är att vara i mötet i stället för att definiera bemötandet i förväg (Garrison 2004, s. 94 ff.). Möjligheten att anta ett sådant förhållningssätt är i princip obefintligt om läraren avser att följa de lagar och riktlinjer som i dag styr skolans verksamhet. En konsekvens av denna utveckling är att mindre utrymme ges till den specifika läraren att bedöma de lokala förutsättningarna och den egna positionen. Att gå in i ett möte utan att på förhand bestämma riktlinjer för handlandet är inte möjligt i den juridiska logik som numera styr skolverksamheten. Samtidigt har det ramverk som tillkommit medfört att frågan lyfts upp på agendan. Ingen kan längre komma undan med att välja ett förhållningssätt som viker undan i en tid där frågan hamnat i strålkastarljuset.

\section{Slutord}

På ett plan menar jag att det är möjligt att se en motsatt rörelse i skolan än i samhället i stort. Samtidigt som utrymmet för främlingsfientliga uttryck tenderar att utvidgas i samhället, har yttrandefriheten i skolan fått snävare juridiska ramar att förhålla sig till. Det gör att utrymmet för 
att uttrycka sina åsikter är betydligt vidare i samhället än i skolan. På ett sätt kan denna åtskillnad vara positiv eftersom den medför att kränkningar i skolan kan förhindras på ett tidigt stadium. Samtidigt är det problematiskt om åsikter som öppet exponeras och uttrycks i samhället, till och med i Sveriges högsta beslutande organ, inte kan diskuteras i skolan. Samtal som förespråkar att kulturella grupper exkluderas kan därmed föras fram i offentligheten men inte diskuteras i klassrummet. I vart fall inte om någon av eleverna ger uttryck för åsikter som bryter mot den uppsatta bedömningsprincipen (kontextuell eller principiell). I valet mellan kommunikativ trygghet och kommunikativ frihet i skolan väljer dagens beslutsfattare det förstnämnda.

Men att någonting inte har tillträde innebär inte att det inte finns. Huruvida en strikt förhindrande princip förebygger eller underbygger främlingsfientlighet i framtiden är en komplicerad fråga att besvara. $\mathrm{Om}$ det likt en läkande kräm får svullnaden att lägga sig eller om det skapar en dold varböld som med tiden spricker återstår att se. Enligt Applebaum (2003, s. 156 ff.; 2008, s. 239 ff.) är det bara en tydlig förhindrande princip som kan bryta ett reproducerande förtryck. Garrison (2004, s. 94 f.) menar å sin sida att det är viktigt att ta tillvara det mellanmänskliga mötet, inte minst när det gäller svåra frågor. Applebaum menar att skolan måste garanterar att förtryck inte förekommer, vilket gör att trygghet blir ett kommunikativt ideal att sträva efter. Om principen att hålla ryggen fri går före reflekterande samtal blir det dock svårt att i skolan föra samtal om sådant som är svårt och kan göra ont. Utifrån Garrisons perspektiv finns då en risk för att mellanmänsklig kommunikation blir en underordnad fråga och att skolans förändringspotential går om intet.

De studerade likabehandlingsplanerna visar på att det framför allt är den exkluderande främlingsfientligheten som behandlas i planerna och att den exploaterande främlingsfientligheten hamnar i bakgrunden. I det förebyggande arbetet är det främst den exkluderande främlingsfientliga eleven som framträder. Det är gentemot eleverna som de flesta insatserna riktas. Det är de som ska observeras, de som ska diskutera och bli en del av en gemenskap. Några av handlingsinriktningarna riktas till både elever och personal när de ska utbildas och informeras. Denna åtskillnad mellan elever och personal görs i mindre utsträckning i det förhindrande arbetet. 
Oftast ses såväl elever som personal som potentiellt främlingsfientliga. Även om det finns spår av handlingsinriktningar som fokuserar på den exploaterande främlingsfientligheten (strukturanalyserande och normkritiska handlingar) så är dessa förhållandevis få. Det är vanligare att i likabehandlingsplanerna fokusera på att bemöta individer, än att motverka de strukturer som skapar förutsättningar för individen att verka förtryckande.

\section{Referenser}

Applebaum, Barbara 2003. Social Justice, Democratic Education and the Silencing of Words that Wound. Journal of Moral Education 32, 2, s. I5I-I62. DOI: http://dx.doi.org/I0.I080/0305724032000072924

Applebaum, Barbara 2008. Voice - For Whose Benefit? Identity - At Whose Expense? Changing Minds - At What Cost? A Rejoinder to Jackson. Journal of Moral Education 37, 2, s. 239-243. Dor: http://dx.doi.org/I0.I080/03057240801996917

Arneback, Emma 2008. In the Gray Zone of Free Speech. A Study of Local Policy Documents Against Xenophobia in School. Paper presenterat på NERA 2008 i Turku, Finland.

Arneback, Emma 20I2. Med kränkningen som måttstock. Om planerade bemötanden av främlingsfientliga uttryck i gymnasieskolan. Örebro: Örebro universitet.

Barnombudsmannen 2008. Sverige äger! Barn och unga berättar om sitt land. Stockholm.

Biesta, Gert J. J. \& Burbules, Nicholas 2003. Pragmatism and Educational Research. Lanham: Rowman \& Littlefield Publishers Inc.

Bourdieu, Pierre \& Passeron, Jean-Claude 2008 [1970]. Reproduktionen. Lund: Arkiv förlag.

Cherryholmes, Cleo H. 1999. Reading Pragmatism. New York: Teachers College Press.

Dewey, John 1971 [1892-1893]. Teaching Ethics in the High School, i The Early Works, 1882-1898. Volume 4, I893-I894. Early Essays and The Study of Ethics. A Syllabus. Carbondale: Southern Illinois University Press.

Dewey, John \& Tufts, James Hayden 1985 [1932]. Ethics, i Dewey, John, The Later Works, 1925-I953. Volume 7, 1932. Ethics. Carbondale: Southern Illinois University Press.

Forum för levande historia 20IO. Den mångtydiga toleransen. En studie av gymnasieungdomars attityder läsarret 2009/2010. Stockholm.

Forum för levande historia \& BRÅ 2004. Intolerans. Antisemitiska, homofobiska, islamofobiska och invandrarfientliga tendenser bland unga. Stockholm: Brottsförebyggande rådet.

Garrison, Jim 2004. Ameliorating Violence in Dialogues Across Differences: The Role of Eros and Lógos, i Boler, Megan (red.) Democratic Dialogue in Education. Troubling Speech, Disturbing Silence. New York: Peter Lang Publishing.

Gruber, Sabine 2008. När skolan gör skillnad. Skola, etnicitet och institutionell praktik. Stockholm: Liber. 
Jonsson, Rickard 2007. Blatte betyder kompis. Om maskulinitet och språk i en högstadieskola. Stockholm: Ordfront.

Justitiekanslern 2008. Initiativärende med anledning av en skolas beslut att inte läta ett politiskt parti fä komma till skolan för att sprida tryckt politisk information. Diarienummer 8527-07-22, 24 april.

Landahl, Joakim 2006. Auktoritet och ansvar. Lärares fostrans- och omsorgsarbete i historisk belysning. Stockholm: Arbetslivsinstitutet.

León, René 20or. På väg mot en diversifierad normalitet. Om annorlundahet, normalitet och makt i mötet mellan elever med utländsk bakgrund och den svenska skolan, i Bigestans, Aina \& Sjögren, Annick (red.) Lyssna. Interkulturella perspektiv på multietniska skolmiljöer. Botkyrka: Mångkulturellt centrum.

León, René 2oro. Vid framtidens hitersta gräns. Om maskulina elevpositioner i en multietnisk skola. Botkyrka: Mångkulturellt centrum.

Ljunggren, Carsten 1996. Medborgarpubliken och det offentliga rummet. Om utbildning, medier och demokrati. Uppsala: Uppsala universitet.

Lpf 94. Läroplan för de frivilliga skolformerna. Stockholm: Utbildningsdepartementet.

Mulinari, Diana \& Neergaard, Anders 20Io. Sverigedemokraterna och det teoretiska fältet, i Deland, Mats, Hertzberg, Fredrik \& Hvitfeldt, Thomas (red.) Det vita fältet. Samtida forskning om högerextremism. Uppsala: Historiska institutionen, Uppsala universitet.

Nordgren, Kenneth 2009. Talet om mobbning - ett historiskt perspektiv, i På tal om mobbning - och det som görs. Stockholm: Skolverket.

Prop. 2005/06:38. Trygghet, respekt och ansvar - om förbud mot diskriminering och annan kränkande behandling av barn och elever.

Rimsten, Olle 20IO. Diskriminering och kränkande behandling i forrskola och skola. Stockholm: Norstedts Juridik.

Runfors, Ann 2003. Mångfald, motsägelser och marginaliseringar. En studie av hur invandrarbarn formas i skolan. Stockholm: Bokförlaget Prisma.

SFS i985:II00. Skollag.

SFS 1995:884. Lag om ändring i skollagen (1985:IIOO).

SFS I999:886. Lag om ändring i skollagen (1985:I100).

SFS 2006:67. Lag om förbud mot diskriminering och annan kränkande behandling av barn och elever.

SFS 2008:567. Diskrimineringslag.

SFS 2008:571. Lag om ändring i skollagen (1985:II00).

SFS 2010:800. Skollag.

Skolverket 2002. Rapportering av regeringsuppdrag. Relationer i skolan. En utvecklande eller destruktiv kraft. Dnr OI-200I:2136.

Skolverket 2007. Delredovisning av uppdrag om diskriminering. Dnr 2006:2495.

Skolverket 2009. Allmänna råd och kommentarer for att främja likabehandling och förebygga diskriminering, trakasserier och kränkande behandling. Stockholm.

Skolverket 20Io. Politisk information i skolan. Stockholm. 


\section{ARNEBACK | BEMÖTANDEN AV FRÄMLINGSFIENTLIGHET}

Säfström, Carl Anders \& Östman, Leif 1999. Textanalys. Introduktion till syftesrelaterad kritik. Lund: Studentlitteratur.

Tesfahuney, Mekonnen 1999. Monokulturell utbildning. Utbildning \& Demokrati. Tidskrift för didaktik och utbildningspolitik 8, 3, s. 65-84.

Trondman, Mats I995. Vem talar om framtidens förlorare? Om det svenska småstadssamhällets unga arbetarklassmän, i Bolin, Göran \& Lövgren, Karin (red.) Om unga män. Lund: Studentlitteratur.

Willis, Paul 1983. Fostran till lönearbete. Göteborg: Daidalos och Röda bokförlaget. 


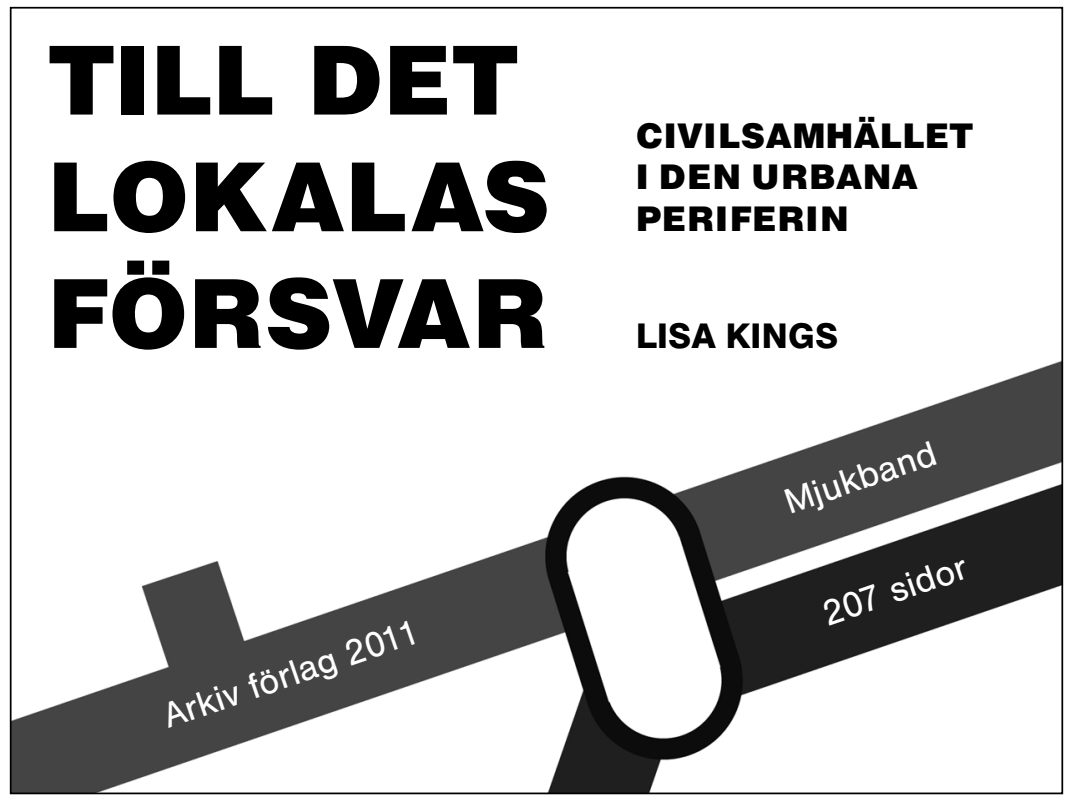

Från invandrarbyrå till flyktingmottagning

Fyrtio års arbete med invandrare och flyktingar på kommunal nivå

Anna-Maria Sarstrand Marekovic

Arkiv förlag 2011, mjukband, 326 sidor

»Läs mer om böckerna på www.arkiv.nu« 